\title{
STUDIES OF THE EFFECTS OF FLAVONOIDS ON ROENTGEN IRRADIATION DISEASE. II. COMPARISON OF THE PROTECTIVE INFLUENCE OF SOME FLAVONOIDS AND VITAMIN C IN DOGS ${ }^{1}$
}

\author{
By JOHN B. FIELD ${ }^{2}$ aNd PAUL E. REKERS \\ (From the Department of Radiation Biology, University of Rochester, School of Medicine and \\ Dentistry, Rochester, New York)
}

(Received for publication February 22, 1949)

The nature of dietary factors contributing to the maintenance of vascular integrity has not, as yet, been satisfactorily elucidated. However, vitamin $C$ appears to play a specific role (1-3) by functioning in some manner to incorporate the vascular cement substance. The significance of other agents in alleviating "vascular purpura" has remained inconclusive.

It has been claimed that "vascular permeability" is dependent upon regulation by the entire class of "vitamin P" substances. Since 1936, the experimental device of eliminating "vitamin P" from the diet of guinea pigs has been the customary approach with markedly contradictory observations recorded (4-10). Recent investigations in this laboratory have utilized a somewhat different principle in a study of exogenous agents contributing to vascular repair $(11,12)$. Roentgen irradiation disease in dogs induces a train of pathological phenomena secondary to a generalized cellular disturbance (13). Since a purpura has been an invariable feature of controlled roentgen irradiation, anti-hemorrhagic agents have been considered, but vitamins $\mathrm{K}, \mathrm{C}$ and the $\mathrm{B}$ complex and calcium have proven ineffective (14). When the flavonol glucoside, rutin, was given to $350 \mathrm{r}$ wholebody, single-dose irradiated dogs, not only was the hemorrhagic diathesis significantly reduced, but mortality fell from 60 per cent to 11 per cent $(11,12)$. The control of purpura was achieved in the presence of marked thrombocytopenia and other typical manifestations of irradiation disease.

1 This paper is based on work performed under contract No. W-7401-Ewf 49 for the Atomic Energy Project at the University of Rochester. The authors gratefully acknowledge the continued counsel of Dr. H. Blair, Director, and Dr. A. H. Dowdy, former Director, Atomic Energy Commission, University of Rochester.

2 Present address: The New York Hospital and Department of Medicine, Cornell University Medical College, New York 21.
Thus, it has been proposed that rutin either decreases the rate of vascular disintegration, or increases its repair (12).

The purpose of this report is to summarize briefly observations on the activity of other substances of the flavonoid and related groups and to indicate the relationship of these substances with vitamin $\mathrm{C}$ in the irradiated dog.

\section{METHODS}

Dogs of the beagle strain, identical to those utilized in the previous study (12) were used throughout. Diet, the manner of animal care and recording of observations were performed as before. Irradiation and hematological methods have already been described (12). The dosage in all these studies delivered to the dorsum of the skin of the dogs was $350 \mathrm{r}$. This value was established with each irradiation by a direct trial measurement with the Victoreen ionization chamber.

The most reliable and consistent basis for evaluation of the value of anti-irradiation agents has been a consideration of the end-mortality of treated and control dogs. A statistical analysis with the $\mathrm{X}^{2}$-test indicated the minimum number of dogs required in the testing of an agent to validate a deviation from control mortality. Further, this analysis assisted to establish the significance within a 2-5 per cent probability level. Table I serves to illustrate this consideration. Thus, based on a mortality of 60 per cent amongst 37 untreated control dogs, an experimental mortality of 10 per cent would have a 74 per cent chance of detection and validation when 10 dogs were used in the trial; 53 per cent when six dogs were used. A mortality of 20 per cent would have a 38 per cent chance of detection when 10 dogs were tested, 26 per cent when using six dogs.

In view of the limited supply of test animals and of some scarce compounds, usually five or six dogs were utilized in each trial. Thus, with numbers such as these, significance can only be attached to results indicating a mortality no greater than one dog in each group of five.

Test substances were usually given in single doses of $50 \mathrm{mg}$. for purposes of direct comparison with results obtained with the same dose of rutin. The compounds were given orally in gelatin capsules three times daily beginning one week prior to irradiation and continuing until 28 days post-radiation. The consumption of these 
TABLE I

Evaluation of significance of test groups

Probability of detecting a reduction of mortality from 60 per cent (based on a sample of 37 control animals) when the $\mathrm{X}^{2}$-test is used for a test of significance.*

\begin{tabular}{|c|c|c|c|c|c|c|c|c|c|c|c|c|}
\hline \multirow{4}{*}{$\begin{array}{c}\text { If the } \\
\text { number } \\
\text { of experi- } \\
\text { mental } \\
\text { animals } \\
\text { is: }\end{array}$} & \multicolumn{12}{|c|}{ If the significance level for rejection of the null hypothesis is: } \\
\hline & \multicolumn{4}{|c|}{$10-5 \%$} & \multicolumn{4}{|c|}{$5-2 \%$} & \multicolumn{4}{|c|}{$2-0 \%$} \\
\hline & \multicolumn{12}{|c|}{ If the true mortality of experimental animals is: } \\
\hline & $10 \%$ & $20 \%$ & $30 \%$ & $40 \%$ & $10 \%$ & $20 \%$ & $30 \%$ & $40 \%$ & $10 \%$ & $20 \%$ & $30 \%$ & $40 \%$ \\
\hline $\begin{array}{r}6 \\
8 \\
10 \\
12 \\
15 \\
20\end{array}$ & $\begin{array}{r}53 \\
81 \\
93 \\
97 \\
99 \\
100\end{array}$ & $\begin{array}{l}26 \\
50 \\
68 \\
79 \\
84 \\
91\end{array}$ & $\begin{array}{l}12 \\
26 \\
38 \\
49 \\
51 \\
61\end{array}$ & $\begin{array}{r}5 \\
11 \\
17 \\
22 \\
22 \\
25\end{array}$ & $\begin{array}{l}53 \\
81 \\
74 \\
89 \\
94 \\
99\end{array}$ & $\begin{array}{l}26 \\
50 \\
38 \\
56 \\
65 \\
80\end{array}$ & $\begin{array}{l}12 \\
26 \\
15 \\
25 \\
30 \\
42\end{array}$ & $\begin{array}{r}5 \\
11 \\
5 \\
8 \\
9 \\
13\end{array}$ & $\begin{array}{r}0 \\
43 \\
74 \\
66 \\
82 \\
96\end{array}$ & $\begin{array}{r}0 \\
17 \\
38 \\
27 \\
40 \\
63\end{array}$ & $\begin{array}{r}0 \\
6 \\
15 \\
8 \\
13 \\
24\end{array}$ & $\begin{array}{l}0 \\
2 \\
5 \\
2 \\
3 \\
5\end{array}$ \\
\hline
\end{tabular}

* Certain minor inconsistencies result from approximations in the application of $\mathrm{X}^{2}$.

test substances was facilitated by incorporating the capsule in approximately 10-20 grams of fresh ground beef. The control dogs received an equal quantity of meat three times daily.

\section{EXPERIMENTAL}

\section{Biologic response to irradiation}

When 37 dogs were given the standard total body single dose of $350 \mathrm{r}$ roentgen irradiation, typical leukopenia, thrombocytopenia and anemia were followed by hemorrhagic signs and gross bleeding in 64 per cent, while 60 per cent of the dogs succumbed in 20 (13-30) days. When the flavonol glucoside, rutin, was administered continually pre- and post-radiation to 27 dogs, 22 per cent developed a purpuric tendency and only 11 per cent died in 21 (16-31) days (Table II). A significant change from untreated controls was a reduction in the hemorrhagic diathesis $(11,12)$. It has already been noted that rutin had little or no effect upon the panhematopenia of the irradiation disease.

\section{Effect of flavonoids in irradiated dogs}

A variety of substances in the flavonoid series have been tested in the standard manner in the $350 \mathrm{r}$ irradiated dog. These include the flavonol glucosides hesperidin, ${ }^{3}$ naringin ${ }^{3}$ and quercitrin, ${ }^{4}$

3 Furnished by Mr. A. J. Lorenz, Director of the laboratories, and Mr. W. E. Baier, Manager, California Fruit Growers' Exchange, Ontario, California.

4 Obtained from S. B. Penick \& Co., New York, N. Y.
TABLE II

"Active" flavonoids influencing the course of irradiation disease

\begin{tabular}{|c|c|c|c|c|c|c|}
\hline & Nun & $\begin{array}{l}\text { ber of } \\
\text { ges }\end{array}$ & $\begin{array}{l}\text { Mor- } \\
\text { tality }\end{array}$ & $\begin{array}{l}\text { Surv } \\
\text { post-rad }\end{array}$ & $\begin{array}{l}\text { ival } \\
\text { diation }\end{array}$ & \begin{tabular}{|c} 
Exhib- \\
iting \\
gross \\
bleed-
\end{tabular} \\
\hline $\begin{array}{l}\text { Control } \\
\text { Rutin } \\
\text { Hesperidin } \\
\text { Morin } \\
\text { Homoerio- } \\
\text { dictyol } \\
\text { Epim-d- } \\
\text { catechin }\end{array}$ & $\begin{array}{c}\text { Started } \\
37 \\
27 \\
6 \\
6 \\
5 \\
10\end{array}$ & \begin{tabular}{|c} 
Survived \\
15 \\
24 \\
5 \\
6 \\
5 \\
9
\end{tabular} & $\begin{array}{c}\text { per } \\
\text { cent } \\
60 \\
11 \\
17 \\
0 \\
0 \\
0 \\
10\end{array}$ & 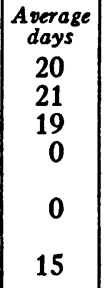 & 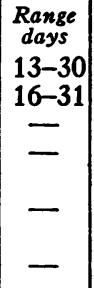 & $\begin{array}{c}\text { per cent } \\
64 \\
22 \\
100 \\
0 \\
20 \\
50\end{array}$ \\
\hline
\end{tabular}

* This includes even mild gingival oozing and petechiae formation.

the aglucone, quercitin, ${ }^{5}$ and the derivatives, epimerized d-catechin, ${ }^{6}$ homoeriodictyol, ${ }^{4}$ hesperidin methyl chalcone, ${ }^{3}$ esculin ${ }^{7}$ and morin. ${ }^{8}$ Because of the distinct differences in protective effectiveness observed with these substances it has been convenient to classify them roughly as "active" and "inactive." Accordingly, the results of these tests are summarized in Tables II and III. Data

5 Furnished by Dr. J. F. Couch, Eastern Regional Research Laboratory, U. S. Department of Agriculture, Philadelphia, Pennsylvania.

6 Furnished through Dr. E. L. Sevringhaus, HoffmannLa Roche, Inc., Nutley, New Jersey.

7 Obtained from the Mercantile Import Company, New York, N. Y.

8 Obtained from the Eastman Kodak Company, Rochester, New York. 
TABLE III

Substances with no activity in influencing the course of irradiation disease

\begin{tabular}{|c|c|c|c|c|c|c|}
\hline & \multicolumn{2}{|c|}{$\begin{array}{l}\text { Number of } \\
\text { dogs }\end{array}$} & \multirow{2}{*}{$\begin{array}{c}\begin{array}{c}\text { Mor- } \\
\text { tality }\end{array} \\
\begin{array}{c}\text { per } \\
\text { cent }\end{array}\end{array}$} & \multicolumn{2}{|c|}{$\begin{array}{l}\text { Post-radiation } \\
\text { survival }\end{array}$} & \multirow{2}{*}{$\begin{array}{c}\begin{array}{c}\text { Exhib- } \\
\text { iting } \\
\text { gross } \\
\text { bleeding }\end{array} \\
\text { per cent } \\
64\end{array}$} \\
\hline & Started & Survived & & $\begin{array}{c}\text { Average } \\
\text { days }\end{array}$ & $\begin{array}{c}\text { Range } \\
\text { days }\end{array}$ & \\
\hline $\begin{array}{l}\text { Control } \\
\text { Hesperidin } \\
\text { methyl }\end{array}$ & 37 & 15 & 60 & 20 & $13-20$ & 64 \\
\hline $\begin{array}{l}\quad \text { chalcone } \\
\text { Quercitin } \\
\text { Esculin } \\
\text { Quercitrin } \\
\text { Naringin }\end{array}$ & $\begin{array}{l}6 \\
6 \\
6 \\
9 \\
6\end{array}$ & $\begin{array}{l}2 \\
3 \\
3 \\
5 \\
3\end{array}$ & $\begin{array}{l}67 \\
50 \\
50 \\
44 \\
50\end{array}$ & $\begin{array}{l}17 \\
14 \\
15 \\
16 \\
21\end{array}$ & $\begin{array}{l}13-22 \\
12-15 \\
13-19 \\
12-22 \\
17-28\end{array}$ & $\begin{array}{r}100 \\
67 \\
100 \\
78 \\
50\end{array}$ \\
\hline $\begin{array}{l}\text { Sodium } \\
\text { gentisate } \\
\text { Dopa }\end{array}$ & $\begin{array}{l}5 \\
6\end{array}$ & $\begin{array}{l}2 \\
3\end{array}$ & $\begin{array}{l}40 \\
50\end{array}$ & $\begin{array}{l}19 \\
14\end{array}$ & $\begin{array}{l}15-22 \\
12-15\end{array}$ & $\begin{array}{l}80 \\
50\end{array}$ \\
\hline
\end{tabular}

obtained with the feeding of rutin are given in Table II to provide some basis of comparison.

In brief, it is to be noted that as observed with rutin, treatment with hesperidin, epimerized $d$ catechin, homoeriodictyol and morin reduced the incidence of hemorrhage and mortality of the irradiated dogs (Table II). Animals which succumbed from the effects of irradiation were grossly similar whether or not a flavonoid was given; hypoplasia of hematopoietic centers, generalized purpura and visceral hemorrhages were always observed. In general, dogs which survived exhibited fewer and smaller induced petechiae. The results from careful hematological studies can be summarized as follows: averaged values from dogs treated with the substances listed in Table III were identical with those of the untreated dogs while the changes seen in the peripheral blood of dogs given the compounds in Table II resembled those recorded for rutin-treated irradiated dogs (12). In the latter, the significant differences observed were a reduced rate of anemia formation, an increase in erythroblasts and nucleated red blood cells, and a significantly lower sedimentation rate.

\section{Effect of other agents in irradiated dogs}

Since flavanones can be degraded in vitro to a benzopyrone, it appeared possible that the latter type of compound might retain certain of the antiirradiation effects of the parent flavonoids. Accordingly, coumarin ${ }^{8}$ was selected as an illustrative compound and tested in the usual fashion. Of six dogs, only two (33 per cent) succumbed 15
(12-19) days after irradiation with some reduction in hemorrhagic tendencies.

In vitro tests (15) have indicated that members of the "vitamin P" group are effective in inhibiting the activity of hyaluronidase. A suggestion was entertained that increased hyaluronidase activity in the roentgen irradiation disease might induce certain features of the vascular dysfunction and "disintegration" (16). ${ }^{9}$ This was fortified by reports that "vitamin P" compounds possessed antihyaluronidase activity in in vitro tests (15). The recent note of Meyer (17) of potent hyaluronidase inhibitors in the quinoid structures raised the possibility that these substances might also influence the course of irradiation disease. Thus, 3, 4-dihydroxyphenyl alanine (dopa) ${ }^{6}$ and sodium gentisate $^{6}$ were tested in the standard manner and the data are summarized in Table III. Although only two of five dogs ( 40 per cent) treated with sodium gentisate succumbed, the surviving animals were critically ill. It is to be noted that in so small a test series, the fate of one animal will influence the mortality by 20 per cent. In no significant manner did the hyaluronidase inhibitors influence the course of irradiation disease in dogs.

\section{Effect of ascorbic acid on the anti-irradiation ac- tivity of vitamin $P$ compounds}

Twelve dogs were given $100 \mathrm{mg}$. of 1 -ascorbic acid orally three times daily beginning one week pre-radiation, and after the standard exposure to $350 \mathrm{r}$ the test substance was given four additional weeks (12). Six dogs (50 per cent) succumbed after 12-14 days post-radiation and the clinical course and hematological data of all animals were identical to the control irradiated dogs (Table IV). Subsequently this treatment, which had been ineffective in itself, was combined with the substances selected from the "inactive" list in Table III. These were hesperidin methyl chalcone and quercitin. Thus, $100 \mathrm{mg}$. of ascorbic acid plus $50 \mathrm{mg}$. of hesperidin methyl chalcone were given orally three times daily to five dogs, and $100 \mathrm{mg}$. of ascorbic acid plus $50 \mathrm{mg}$. of quercitin were given to 10 dogs. The medication was continuous through-

${ }^{9}$ In other studies, we have observed that neither irradiation disease nor rutin nor a combination of both, produced an alteration in the urinary excretion of hyaluronidase from the dog. Incubating dog blood with hyaluronidase resulted in no hematological changes. 
TABLE IV

Effect of supplementing ascorbic acid with inactive flavonoids on the course of irradiation disease

\begin{tabular}{l|c|c|c|c|c|c}
\hline \hline & \multicolumn{2}{|c|}{$\begin{array}{c}\text { Number of } \\
\text { dogs }\end{array}$} & $\begin{array}{c}\text { Mor- } \\
\text { tality }\end{array}$ & \multicolumn{2}{|c|}{$\begin{array}{c}\text { Survival } \\
\text { post-radiation }\end{array}$} & $\begin{array}{c}\text { Exhib- } \\
\text { iting } \\
\text { gross } \\
\text { bleeding }\end{array}$ \\
\hline & $\begin{array}{c}\text { Started } \\
\text { per }\end{array}$ & $\begin{array}{c}\text { Survived } \\
15\end{array}$ & $\begin{array}{c}\text { pent } \\
\text { cent } \\
60\end{array}$ & $\begin{array}{c}\text { Average } \\
\text { days } \\
20\end{array}$ & $\begin{array}{c}\text { Range } \\
\text { days } \\
13-20\end{array}$ & $\begin{array}{c}\text { per cent } \\
64\end{array}$ \\
$\begin{array}{c}\text { Control } \\
\text { Ascorbic } \\
\text { acid* }\end{array}$ & 12 & 6 & 50 & 13 & $12-14$ & 100 \\
$\begin{array}{c}\text { Ascorbic } \\
\text { acid plus } \\
\text { quercitin }\end{array}$ & 10 & 9 & 10 & 11 & - & 70 \\
$\begin{array}{c}\text { Ascorbic } \\
\text { acid plus } \\
\text { hesperidin } \\
\text { methyl } \\
\text { chalcone }\end{array}$ & 5 & 1 & 80 & 19 & $17-21$ & 80 \\
\hline
\end{tabular}

* $100 \mathrm{mg}$. by mouth given three times daily beginning seven days before irradiation and thereafter for 28 days.

out in the usual manner from one week preradiation to four weeks post-radiation. The results of these tests are summarized in Table IV. The hematological data from all groups listed in this table were very similar.

\section{DISCUSSION}

It has been suggested that the inconsistencies in the past studies on "vitamin P" have arisen primarily because the need for this agent is not easily demonstrated under normal physiologic circumstances. Another complication encountered has been the derivation of an adequate diet free of the universally distributed flavonoids. A further deterrent has been an ignorance of the species requirements for "vitamin P." Certainly, the latter has been a formidable obstacle in the program of this laboratory and to date, consistent data have been obtained only with the dog but not with the rabbit, rat, guinea pig or mouse. ${ }^{10}$

The technique of acute whole-body, mid-lethal irradiation in the dog produces predominantly a vascular derangement detectable most directly in the clinical course of the animal. Autopsy has demonstrated the existence of multiple widespread vascular lesions although the usual histopathological examination of vessels in the irradiated tissues has not revealed the origin of the disintegration. The nature of a true "vascular purpura" is discussed by Hiramatsu (18). He differentiates this

\footnotetext{
${ }^{10}$ Field, J. B., and Rekers, P. E. To be published.
}

state from a "purpura of the blood" which includes a thrombocytopenia and presumably the existence of any anticoagulant such as heparin (14).

In the course of these studies with the flavanones it has been observed that neither is the course of the usual post-radiation panhematopenia and severe thrombopenia altered significantly by protective flavonoids, nor has it been observed that these agents inhibit heparin. ${ }^{11}$ Thus, it might appear that these agents affect the vascular system directly, perhaps participating as a principal in the "wear and tear" of a part or all of the vascular system, inhibiting its degeneration and either stimulating, or being incorporated in, its regeneration. In support of this proposition is the observation that the process of vascular disintegration together with universal cellular catabolism and necrosis are accelerated in the irradiated animal. It appears that the "strain" of repair elicits the positive anti-hemorrhagic effects of the flavonoids in the mid-lethal irradiated dog when the usual dietary complement of these agents becomes inadequate.

"Vitamin P" has been identified as a wide variety of flavonoid compounds in the past $(4,5,19$ 21). Claims of activity have been made for many of the substances included in the present report. Eventually our present program envisions the "screening" of an even larger number of compounds with the dog irradiation technique and the results of these tests will be given on subsequent occasions. However, it appears that the following flavanones possess in common, an approximately equal capacity to protect the $350 \mathrm{r}$ x-irradiated $\operatorname{dog}$; they are rutin, hesperidin, epimerized d-catechin, homoeriodictyol and morin. It is quite possible that there exists a considerable qualitative and quantitative variation of anti-hemorrhagic capacity amongst these substances. However, it would be hazardous to draw anything but limited conclusions from the present data. The purpose of this report is simply to identify compounds which have "protected" the irradiated dog under given specific conditions.

Since the "active" agents possess the same fundamental flavanone structure it appeared incon-

11 Heparin will increase the sedimentation rate of blood, and although rutin in vivo and in vitro reduces increased sedimentation rates, it does not affect the prolonged coagulation time of heparinized blood. 
sistent that other very similar compounds and flavonol glucosides as quercitrin and naringin failed to influence the course of irradiated dogs. Particularly disappointing was the performance of quercitin, the aglucone of rutin. With the latter substance only 11 per cent of the dogs succumbed to the effects of irradiation. Given quercitin, 50 per cent of the dogs died with severe irradiation disease. Thus, the demonstration of the synergistic action of ascorbic acid when given concomitantly with quercitin, which reduced mortality to 10 per cent, is of considerable interest. The inter-relationship of vitamin C and "vitamin P" has been sharply debated. Zilva (8) indicated that ascorbic acid alone would maintain capillary repair while Szent-Gyorgyi suggested that ascorbic acid probably exerts a catalytic effect potentiating the action of "vitamin P." The present data support the latter view and it may be predicted that supplementary treatment with ascorbic acid may potentiate an anti-hemorrhagic action of other flavanones as naringin and quercitrin reported at present as "inactive." Study of this problem is in progress.

Apparently degradation of the parent flavanone molecule sacrifices anti-hemorrhagic activity. Thus, esculin and hesperidin methyl chalcone failed to "protect" irradiated dogs even when ascorbic acid supplemented the chalcone in one test. These findings are in disagreement with reports of high "vitamin P" activity for these substances as derived through indirect assay methods $(20,21)$, or when petechiae formation was measured in rats with a thrombocytopenia resulting from treatment with an anti-platelet serum (22). Two of the six dogs (33 per cent) given coumarin succumbed compared with a mortality of 60 per cent in untreated dogs. Until a larger series of dogs is tested, this result cannot be interpreted as any more than a suggestion that a molecule smaller than the flavanones may "protect" irradiated dogs.

The possibility that the "spreading factor," hyaluronidase, plays a role in the course of roentgen irradiation disease and may be implicated "in accentuating capillary fragility rather than inducing direct change in capillary permeability" (16) appears unlikely. This impression is supported by the failure of potent hyaluronidase inhibitors as dopa and sodium gentisate to influence the course of irradiation disease. Contrary to other claims (15) that "vitamin P" inhibits hyaluronidase, neither has the administration of large quantities of flavonoids had any effect on the hyaluronidase levels in the urine of the normal dog nor have preliminary tests implicated hyaluronidase in the evolution of roentgen irradiation disease of dogs.

\section{SUMMARY}

1. Exposed to $350 \mathrm{r}$ single-dose, total-body $\mathrm{x}$-irradiation, 60 per cent ( 22 of 37 ) untreated control dogs succumbed with a prominent hemorrhagic syndrome. Five flavanone substances appeared roughly of equal activity in reducing the hemorrhagic signs of the irradiation disease when administered continuously pre- and post-radiation. When rutin was fed, 11 per cent (three of 27) of the dogs succumbed; with hesperidin, 17 per cent (one of six); with epimerized d-catechin, 10 per cent (one of 10); and with homoeriodictyol none of five and with morin, none of six irradiated dogs succumbed.

2. Other flavonoids and their derivatives did not significantly reduce either the mortality or hemorrhagic changes in irradiated dogs. These included hesperidin methyl chalcone, esculin, quercitin, quercitrin and naringin. With the benzopyrone, coumarin, 33 per cent (two of six) of the dogs succumbed suggesting slight anti-irradiation activity.

3. Ascorbic acid alone failed to influence the course of irradiation disease and 50 per cent (six of 12) of treated dogs died. However, when ascorbic acid was given simultaneously with quercitin which by itself was ineffective ( 50 per cent mortality), only 10 per cent (one of 10 ) dogs succumbed exhibiting reduced signs of the disease. No increase in protective activity occurred when ascorbic acid and hesperidin methyl chalcone were given together.

4. It is suggested that previous misunderstanding of the nature of "vitamin $P$ " has arisen from both the failure to recognize that several flavonone analogues possess very similar anti-hemorrhagic "activity" and that ascorbic acid has the capacity to potentiate "activity" in other flavanones.

5. Potent hyaluronidase inhibitors as dopa and sodium gentisate failed to influence the course of irradiation disease in dogs. It is suggested that the "spreading factor," hyaluronidase, plays little or no role in the evolution of this disorder. 


\section{BIBLIOGRAPHY}

1. Wolbach, S. B., Controlled formation of collagen and reticulum. A study of the source of intercellular substance in recovery from experimental scorbutus. Am. J. Path., 1933, 9, 689.

2. von Jeney, A., and Törö, E., Die Wirkung der Ascorbinsäure auf die Faserbildung in Fibroblastkulturen. Virchow's Arch. f. path. Anat., 1936, 298, 87.

3. Wolbach, S. B., The pathologic changes resulting from vitamin deficiency. J. A. M. A., 1937, 108, 7.

4. Armentano, L., Bentsath, A., Beres, T., Rusznyak, I., and Szent-Györgyi, A., Uber den Einfluss von Substanzen den Flavongruppe auf die Permeabilität der Kapillaren. Vitamin P. Deutsche med. Wchnschr., 1936, 62, 1325.

5. Rusznyak, S., and Benko, A., Experimental vitamin P deficiency. Science, 1941, 94, 25.

6. Rusznyak, S., and Szent-Györgyi, A., Vitamin P: flavonols as vitamins. Nature, 1936, 138, 27.

7. Zacho, C. E., Influence of ascorbic acid and of citrin on capillary resistance of guinea pigs. Acta path. et microbiol. Scandinav., 1939, 16, 144.

8. Zilva, S. S., Vitamin P. Biochem. J., 1937, 31, 915.

9. Moll, T., Zur Frage des Vitamin P. Klin. Wchnschr., 1937, 16, 1653.

10. Bentsath, A., Rusznyak, S., and Szent-Györgyi, A., Vitamin P. Nature, 1937, 139, 326.

11. Rekers, P. E., and Field, J. B., Control of hemorrhagic syndrome and reduction in $x$-irradiation mortality with a flavanone. Science, 1948, 107, 16.

12. Field, J. B., and Rekers, P. E., Studies of the effects of flavonoids on roentgen irradiation disease. I. Protective influence of rutin in irradiated dogs. Am. J. M. Sc., 1949. In press.
13. Prosser, C. L., Painter, E. E., Lisco, H., Brues, A. M., Jacobson, L. O., and Swift, M. N., The clinical sequence of physiological effects of ionizing radiation in animals. Radiology, 1947, 49, 299.

14. Allen, J. G., and Jacobson, L. O., Hyperheparinemia : cause of the hemorrhagic syndrome associated with total body exposure to ionizing irradiation. Science, 1947, 105, 388.

15. Beiler, J. M., and Martin, G. J., Inhibitory action of vitamin $\mathrm{P}$ compounds on hyaluronidase. J. Biol. Chem., 1947, 171, 507.

16. Chambers, R., and Zweifach, B. W., Intercellular cement and capillary permeability. Physiol. Rev., 1947, 27, 436.

17. Meyer, K., Ragan, C., and Weinshelbaum, H., Inhibition of hyaluronidase by hydroquinones and quinones. Federation Proc., 1948, 7, 173.

18. Hiramatsu, N., Studies on "vitamin P" (hesperidin). III. The effect of hesperidin upon experimental purpura in guinea pigs. Hifuka Hitsuryokika Zassi (Jap. J. Dermat. \& Urol.), 1941, 49, 286.

19. Scarborough, H., Observations on the nature of vita$\min \mathbf{P}$ and the vitamin $\mathrm{P}$ potency of certain foodstuffs. Biochem. J., 1945, 39, 271.

20. Haley, T. J., Clark, W. G., and Geissman, T. A., Studies on "vitamin P." I. Topically applied "vitamin P"-like substances on the mammalian capillary bed. Proc. Soc. Exper. Biol. \& Med., 1947, 65, 202.

21. Lavollay, J., Sur la vitamine P. Action de l'esculoside et de l'esculétol sur la résistance des capillaries. Comp. Rend. Soc. Biol., 1945, 139, 270.

22. Randall, L. O., and Sevringhaus, E. L., Effect of "vitamin P"-like substances on capillary resistance in thrombocytopenic purpura in rats. Arch. Biochem., 1949. In press. 